\title{
Effect of Cowpea (Vigna unguiculata) Pasture Grazing on Growth, Gastrointestinal Parasite Infection and Immune Response Biomarkers of Goat
}

\author{
Mulumebet Worku ${ }^{1}$, Sarah Adjei-Fremah ${ }^{1}$, Niki Whitley ${ }^{2}$ \& Louis Jackai ${ }^{3}$ \\ ${ }^{1}$ Department of Animal Sciences, North Carolina Agricultural and Technical State University, Greensboro, NC, \\ USA \\ ${ }^{2}$ Pettigrew Center, Fort Valley State University, Fort Valley, GA, USA \\ ${ }^{3}$ Department of Natural Resources and Environmental Design, North Carolina Agricultural and Technical State \\ University, Greensboro, NC, USA \\ Correspondence: Mulumebet Worku, Department of Animal Sciences, North Carolina A\&T State University, \\ 1601 East Market Street, Greensboro, NC, USA. Tel: 1-336-285-4816. E-mail: worku@ncat.edu
}

Received: September 15, 2017

Accepted: November 9, 2017

Online Published: December 15, 2017

doi:10.5539/jas.v10n1p27

URL: https://doi.org/10.5539/jas.v10n1p27

The research is financed by USDA-NIFA Evans-Allen grant and Agricultural Research Program of the College of Agriculture and Environmental Science, North Carolina Agricultural and Technical State University.

\begin{abstract}
The objective of this study was to evaluate the effect of grazing cowpea pastures on growth, parasite egg count and biomarkers of immune response in goats. Spanish and Savannah goats $(n=48)$ stratified by initial body weight $(42.0 \pm 7.0 \mathrm{~kg})$ and fecal egg count (FEC), were randomly assigned to three pasture forages (Cowpea varieties: Mississippi silver (MS), or Iron and Clay (IC) or Pearl millet (PM) as control with 4 replicates, for a 28-day feeding trial. Forage samples collected at the start of the study were analyzed for nutrients, chemical and polyphenols content. Body weight, body condition score, and fecal egg count were measured weekly. Blood was collected from goats on days 0 and 28 for PCV and white blood cell differential counts. The concentration of total proteins, prostaglandin E2 (PGE2) and total antioxidant capacity (TAC) were evaluated in blood serum. Concentration of DNA isolated from fecal samples was used as a measure of gut health. Goats grazed on cowpea forage (MS and IC) had higher body weight $(p=0.01)$ compared to goats grazed on PM. Percent lymphocyte ( $p=$ $0.008)$ and neutrophil $(p=0.013)$ increased in MS fed goats. Goats grazed on MS pasture had decreased FEC $(p=$ $0.03)$ also. Cowpea pasture grazing had no effect on serum protein concentration, PCV and BCS $(p>0.05)$, but decreased PGE2 concentration in serum. The concentration of TAC in serum, increased at day $28(p<0.05)$. The concentration of fecal microbial DNA decreased in all the treatment groups at day 28. Cowpea forage grazing had an impact on body weight, FEC, and blood serum parameters (PGE2, TAC) in goats. These results demonstrate that freshly grazed cowpea forage has potential impact and benefits on growth and health of goats. Integrating cowpea diet in goat feeding system may enhance growth performance, stimulate and prime the immune system for defense against gastrointestinal parasites.
\end{abstract}

Keywords: antioxidant, cowpea, goats, fecal egg count, prostaglandin E2, innate immunity

\section{Introduction}

Small ruminant production is a growing industry as a result of demographic changes in populations and the global demand for goat and sheep products. Major challenges for producers with economic impact include gastrointestinal nematode (GIN) parasites especially the blood-feeder Haemonchus contortus, that are associated with increased mortality and poor weight gain (Molento, 2009; Hamilton et al., 2017). These challenges reduce meat, milk and fiber production and cause estimated loss of "tens of billions of dollars worldwide" (Roeber, Jex, $\&$ Gasser, 2013). The GIN parasites are typically controlled using anthelmintic drugs, furthermore, overuse of these drugs has resulted in increased resistance rendering this method ineffective in GIN control. The use of bioactive plants containing condensed tannins has been studied and suggested as a potential sustainable 
alternative non-chemical strategy for GIN control in small ruminants (Van Wyk, 2001). Animal feed resources and supplements that decrease gastrointestinal parasites, and improve growth and production are therefore of great interest to producers. Condensed tannin-rich forages with efficacy against GIN include sulla (Hedysarum coronarium; Niezen, et al., 1995), sericea lespedeza (Lespedeza cuneata; Min et al., 2004), sainfoin (Onobrychus viciifolia; Heckendorn et al., 2006), birdsfoot trefoil (L. corniculatus; Heckendorn et al., 2007). Sericea lespedeza a legume with high amounts of condensed tannins, has an anthelmintic effect (Min et al., 2004) when grazed as a fresh forage (Terrill et al., 2009; Mechineni et al., 2014) and impacts immune response gene expression (Worku et al., 2016; Asiamah et al., 2016).

Cowpea (Vigna unguiculata L. Walp), is a heat and drought-tolerant annual legume adapted to a wide range of soil and climate conditions (Singh et al., 2010). It is cultivated for its seeds and fodder, used as food for humans and feed for animals respectively (Singh et al., 2003). In livestock production, cowpea is fed as fresh forage, hay, stovers, or haulums. Cowpea is highly nutritious, contains good quality proteins and carbohydrates (Sreerama et al., 2012), and has been suggested as a protein supplement for improved nutrition of ruminants (Etana et al., 2013). Additionally, cowpea forage contains phenolic compounds including flavonoids, tannins (Cai et al., 2003) and these bioactive compounds have antioxidant properties that help to combat oxidative stresses and diseases (Adjei-Fremah, 2017). In vitro studies by Adjei-Fremah et al. (2015) have shown that cowpea polyphenol extracts impact antioxidant status in bovine blood and regulate gene expression (Adjei-Fremah et al., 2016a, 2016b, 2016c, 2016d). Cowpea plants are grazed by cattle (Pitman et al., 2015), and sheep and goats (Mubi, Midau \& Hamdalla, 2015; Adjei-Fremah, 2016c) as a summer legume. More recently, cowpea used as a summer finishing diet in cattle resulted in improved meat quality and marbling score, and higher consumer steak preference (Schmidt et al., 2013). It is important to understand goat growth and health performance when allowed to graze fresh cowpea pasture. The objective of this study was to evaluate the effect of cowpea forage on growth, parasite egg count and biomarkers of immune response in goats.

\section{Method}

\subsection{Ethical Statement}

The experimental procedure and protocols used were approved by the North Carolina A\&T State University Institutional Animal Care and Use Committee.

\subsection{Establishment of Feeding Paddocks}

The experiment was conducted at the Upper Piedmont Station, Reidsville, NC. Twelve pasture grazing plots (0.15 ha/each) were established consisting of three main forage groups; 1) Pearl millet (PM; Pennisetum americanum), two varieties of cowpea commonly used as fodder in Southeastern US; 2) Mississippi Silver cowpea (MS), and 3) Iron and Clay cowpea (IC) with 4 replicated paddocks for each forage type. Soil testing on pasture plots was done by the North Carolina Department of Agriculture and Consumer Services (NCDA\&CS) Agronomic division. Commercially purchased seeds of two cowpea varieties (MS and IC) and pearl millet were planted in the plots. The goats were allowed to graze the plots $40 \mathrm{~d}$ after planting. There was adequate forage material in each paddock throughout the $28 \mathrm{~d}$ study period.

\subsection{Chemical Composition of Feed and Extract Preparation}

Forage samples from PM, MS and ID were randomly collected from each paddock, bulked together and sent for chemical analysis at the NCDA\&CS, Food, and Drug Protection Division Laboratory, Raleigh, NC. All chemical analysis were done using Association of Official Analytical Chemists (AOAC) protocols (AOAC, 2000). Leaf samples of PM, MS, and IC were randomly collected from each plot and bulked individually for analysis. Forages were analyzed on dry matter basis for crude protein (CP), unavailable protein (UP), acid detergent fiber $(\mathrm{ADF})$, ash, and mineral elements. Separate forage samples were collected, freeze-dried and used for analyzing total phenolic content and condensed tannin content. Total phenolic content (TPC) was analyzed using the Folin-ciocaulteu method (Singleton et al., 1999) and condensed tannin content (CT) with the vanillin-HCL method (Price et al., 1978). Gallic acid and catechin with known concentrations were used as standards for TPC and CT, respectively. The procedure for extraction and quantification and of TPC and CT was as previously described by Adjei-Fremah et al. (2015). Extracts were prepared from PM, MS, and IC using $80 \%$ methanol(w/w).

\subsection{Animals}

Forty-eight post-weaned goats were selected from the goat herd at the Upper Piedmont Research Station, Reidsville, North Carolina, USA. Two goat breeds Spanish $(n=24)$ and Savannah $(n=24)$ stratified by initial body weight (BW) $(42.0 \pm 7.0 \mathrm{~kg}$ ) and fecal egg counts (FEC), were randomly assigned to 1 of 12 grazing plots (4 
goats per plot) consisting of one of the three experimental forages MS, IC forage and PM (Control). The animals were provided with water ad libitum throughout the study period. Phenotypic parameters such as body weight, body condition score, and FAMACHA score were measured weekly for 4 wks. Body weight was measured using a standard scale. Body condition score was scored on a scale of 1 to 5. FAMACHA was also scored on a scale of 1 to 5 using the FAMACHA eye chart (Kaplan et al., 2004) as previously described by Ekwemalor et al. (2016).

\subsection{Blood Collection and Analysis}

Blood was collected from each animal from the jugular vein on $0 \mathrm{~d}$ and $28 \mathrm{~d}$ in EDTA Vacutainer tubes (Becton, Dickinson and Co., Franklin Lakes, NJ) and immediately stored on ice. Blood was analyzed for total cell count (TC), viable cell counts (VC), packed cell volume (PCV), white blood cells differential counts (WBC). Total cells and viable cells were determined using TC20 automatic cell counter (Bio-rad). Packed cell volume (PCV), an indicator of anemia was evaluated using an aliquot of blood in microcapillary tubes, centrifuged and measured on ahematocrit (Diamon/EC division). White blood cell differential counts using Wright staining method and 100 counts read on alight microscope following the procedure as described by Asiamah et al. (2016). Blood collected into BD vacutainer SST Gel and clot activator serum tubes was used to process serum. The tubes were centrifuged at $4500 \mathrm{rpm}$, at $4{ }^{\circ} \mathrm{C}$ for 30 mins to obtain serum. Serum was stored at $-80{ }^{\circ} \mathrm{C}$ until used for analysis.

\subsection{Fecal Sampling and Analysis}

Fecal samples were collected weekly and analyzed for parasite egg count using the modified McMaster's method. Fecal egg counts were measured in duplicate and the mean was multiplied by 50 (Kaplan et al., 2004). Data for fecal egg counts were log transformed before statistical analysis. Fecal microbial DNA was isolated using the QIAamp stool DNA kit (Qiagen) following the manufacturer's protocol.The concentration and purity of total fecal DNA were measured using a NanoDrop ND-1000 spectrophotometer (Thermo Scientific, DE, USA)

\subsection{Blood Serum Assays}

Serum was analyzed for total protein, prostaglandin E2 (PGE2) and total antioxidant concentrations(TAC). Total serum protein concentration was measured using the Pierce BCA assay kit (Thermo-Scientific, Waltham, MA) following manufacturer's protocol as previously described by Obanla et al. (2016). Bovine serum albumin with known concentrations was used as astandard to quantify the level of proteins in serum samples. The secretion of Prostanglin E2 (PGE2) in serum was measured using a commercial enzyme-linked immunosorbent assay (ELISA; Cayman Chemical, An Arbour, MI) following manufacturer's protocol.

The endogenous total antioxidant capacity in blood serum (i.e. for 0day and 28-day samples) was determined using the OxiSelect ${ }^{\mathrm{TM}}$ TAC assay kit following the manufacturer's protocol (Cell Biolabs Inc., San Diego, CA) as previously described by Adjei-Fremah et al. (2015). The Cell Biolabs' OxiSelect ${ }^{\mathrm{TM}}$ TAC assay measures the total antioxidant capacity of biomolecules from samples through a single electron transfer mechanism. The TAC assay is based on the reduction of copper (II) to copper (I) by antioxidants such as uric acid. Serum samples were analyzed separately with the assay buffer containing copper ion reagent and incubated for $5 \mathrm{~min}$ and absorbance was read at $490 \mathrm{~nm}$ on a microplate reader (Epoch, BioTek). A standard curve $\left(r^{2}=0.99\right)$ using known concentrations of uric acid was used determine the serum total antioxidant capacity.

\subsection{Statistical Analysis}

Statistical analysis was performed using the general linear (PROC MIXED) repeated measure model in SAS (version 9, SAS Institute Inc., Cary, NC) to test for significant difference between means using the model below: $Y_{i j k}=\mu+T_{i}+W_{j}+T W_{i j}+e_{i j k l} ; Y_{i j k}=$ dependent variable, is the observed measurement; $\mu=$ the overall population mean; $T_{i}=$ is the fixed effect of the treatment $i, W_{j}$ is the random effect of time $j, T W_{i j}$ is the interaction of treatment $i$ and time $j, e_{i j k l}=$ random residual effect (error) assumed normally distributed with a mean zero and variance $\sigma^{2} \mathrm{e}$. Body weight, BCS, and FAMACHA score data were analyzed using PROC GLM repeated measure in SAS. Two-way ANOVA was performed on all other data, and a p-value $<0.05$ was considered significant. Pearson's correlation analysis was used to determine the relationship between all the parameters measured.

\section{Results}

\subsection{Chemical Composition of Forage Samples}

Table 1 shows chemical composition in the different forage types grazed. The crude protein content was relatively the same in all the forages. Forages from MS and IC varieties had higher TPC, $298.05 \mathrm{mg} / \mathrm{GAE}$ and $271.34 \mathrm{mg} / \mathrm{GAE}$ respectively than PM (54.92 mg/GAE). The condensed tannin content in MS and IC were 0.52 $\mathrm{mg} / \mathrm{CE}$ and $0.48 \mathrm{mg} / \mathrm{CE}$ separately. There was no CT found in pearl millet forage. 
Table 1. Nutrient and chemical composition in forage samples; Pearl Millet (PM), Mississippi Silver (MS), and Iron and Clay (IC) cowpea

\begin{tabular}{llll}
\hline Chemical composition $^{2}$ & PM & MS & IC $^{1}$ \\
\hline Dry matter,DM (\%) & 17.38 & 20.52 & 19.26 \\
CP (\% of DM) & 23.89 & 21.09 & 24.07 \\
UP(\% of DM) & 1.21 & 1.47 & 0.83 \\
Adjusted crude proetin (\% of DM) & 23.89 & 21.09 & 24.07 \\
ADF (\% of DM) & 28.18 & 15.84 & 15.55 \\
Nitrate ion (\% of DM) & 0.78 & 0.18 & 0.21 \\
Ash (\% of DM) & 10.75 & 14.76 & 15.35 \\
Calcium (\% of DM) & 0.65 & 1.88 & 2.48 \\
Phosphorus (\% of DM) & 0.53 & 0.35 & 0.34 \\
Sulfur (\% of DM) & 0.28 & 0.24 & 0.30 \\
Magnessium (\% of DM) & 0.42 & 0.43 & 0.57 \\
Sodium (\% of DM) & 0.01 & 0.00 & 0.00 \\
Potassium (\% of DM) & 3.08 & 2.42 & 2.06 \\
Copper (ppm) & 14.00 & 8.00 & 11.00 \\
Iron (ppm) & 225.00 & 518.00 & 460.00 \\
Zinc (ppm) & 90.00 & 24.00 & 30.00 \\
Manganese (ppm) & 98.00 & 76.00 & 65.00 \\
Alumnium (ppm) & 0.24 & 1.12 & 1.10 \\
Boron (ppm) & 0.10 & 0.06 & 0.05 \\
Total phenolic content (mg/GAE) & 54.92 & 298.05 & 271.34 \\
Condensed tannin(mg/CAE) & $\mathrm{ND}$ & 0.52 & 0.48 \\
\hline
\end{tabular}

Note. ${ }^{1}$ Goats grazed on these pastures for $28 \mathrm{~d}$;

${ }^{2}$ Chemical constituents in feed were analyzed on dry matter basis (DM) using AOAC standards by North Carolina department of Agriculture and Consumer services, Food and Drug Protection Division Laboratory, Raleigh,NC, and the Food analytical Laboratory, North Carolina A\&T State University;

${ }^{3}$ ND-Not detected.

\subsection{Effect of Forage Type on Body Weight}

The changes in body weight over the $28 \mathrm{~d}$ study period is shown in Figure 1. Body weight was affected by feedtype grazed $(p=0.0023)$. The initial body weight of MS and IC fed goats were slightly lower compared to PM animals. After 7 d, BW slightly increased in PM grazed goats. At 14 d, BW increased in MS-grazed goats and continued to day 28. Body condition score was similar between Savannah and Spanish goats. The interaction effect between BW, goat breed and feedtype was also significant $(p=0.0124)$. The BW increased in MS-grazed Savanna goats $(50.01 \mathrm{~kg})$ compared to MS-grazed Spanish goats $(45.83 \mathrm{~kg})$.

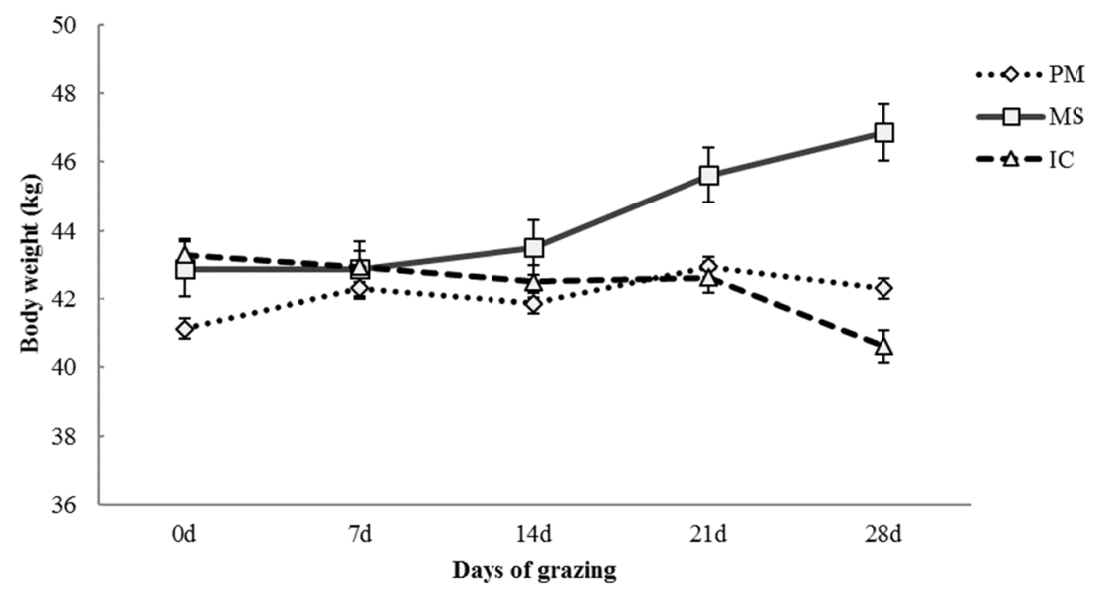

Figure 1. Body weight in goats fed pearl millet (PM), Mississippi silver (MS), and Iron and Clay (IC) cowpea 


\subsection{Effect of Forage Type on PCV, FAMACHA, BCS and WBC}

The BCS, FAMACHA, and PCV (Table 2) were not affected by forage type grazed. The packed cell volume $(\mathrm{PCV})$ for all animals initially $(0 \mathrm{~d})$ was $32 \%$ and remained unchanged throughout the study period. Cowpea had effect on white blood cells differential count especially \% lymphocytes $(p=0.0267)$ and $\%$ neutrophils counts $(p$ $=0.0129$ ). The interaction between goat breed, feedtype and \% lymphocytes was also significant at $p=0.00264$. Lymphocyte counts were highest in PM-grazed Spanish goats (75\%) and lowest in MS-grazed savanna goats (43\%). Feed had no effect on \% monocytes, $\%$ basophil, and \% eosinophil counts. Similarly, the interaction effect between goat breed, forage type and $\%$ neutrophils counts was also significant at $p=0.0094$. Percent neutrophils increased in MS-grazed savanna goats (55\%) than MS-grazed Spanish goats (28\%), IC-grazed Savanna (26\%) and PM-grazed Spanish goats (25\%).

Table 2. Effect of cowpea pasture on hematological parameters in goats

\begin{tabular}{lllll}
\hline Parameter & PM & MS & IC & p-value \\
\hline PCV, \% & 32.0 & 32.7 & 33.1 & $\mathrm{~ns}$ \\
FAMACHA & 3.03 & 2.29 & 2.95 & $\mathrm{~ns}$ \\
BCS & 3.13 & 3.38 & 2.94 & $\mathrm{~ns}$ \\
\hdashline White Blood cells (\%) & & & & \\
Lymphocytes & 73 & 57 & 64 & 0.0297 \\
Monocytes & 1 & 1 & 1 & $\mathrm{~ns}$ \\
Neutrophils & 26 & 42 & 34 & 0.0129 \\
Basophils & 0 & 0 & 0 & $\mathrm{~ns}$ \\
Eosinophils & 0 & 0 & 1 & $\mathrm{~ns}$ \\
\hline
\end{tabular}

\subsection{Effect of Cowpea on Fecal Egg Count}

The effect of forage type on FEC in goats is shown in Figure 2. Fecal egg counts were slightly variable between the three forage groups at day 0 . The forage type grazed had aneffect on FEC $(p=0.026)$ in goats. Although the interaction between FEC and goats breeds was non-significant $(p=0.2406)$, FEC was lower in Spanish compared to Savanah goats. Seven days after initiation of the study, goats grazed on MS cowpea forage had lower FEC compared to IC and PM pasture-grazed animals, and MS effect in reducing FEC was continuous through $21 \mathrm{~d}$ and $28 \mathrm{~d}$ relative to goats grazed on the other feed pastures.

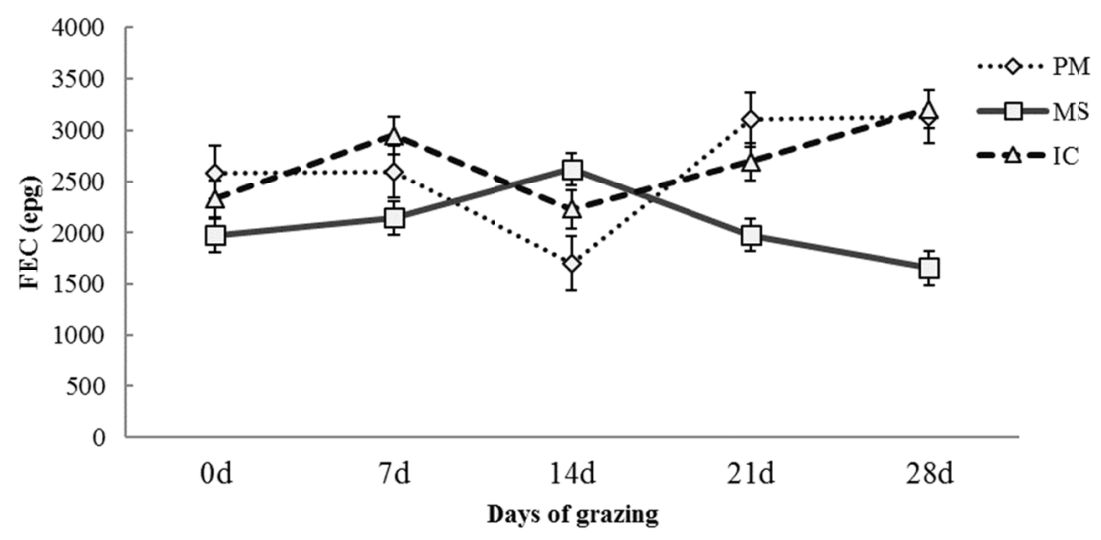

Figure 2. Effect of cowpea pasture grazing on fecal egg count in goats fed pearl millet (PM), Mississippi silver (MS), and Iron and Clay (IC) cowpea

\subsection{Effect of Cowpea Forage on Fecal DNA Concentration}

Fecal DNA concentration is presented in Figure 3. The concentration of fecal microbial DNA decreased in all the treatment groups at day 28. 


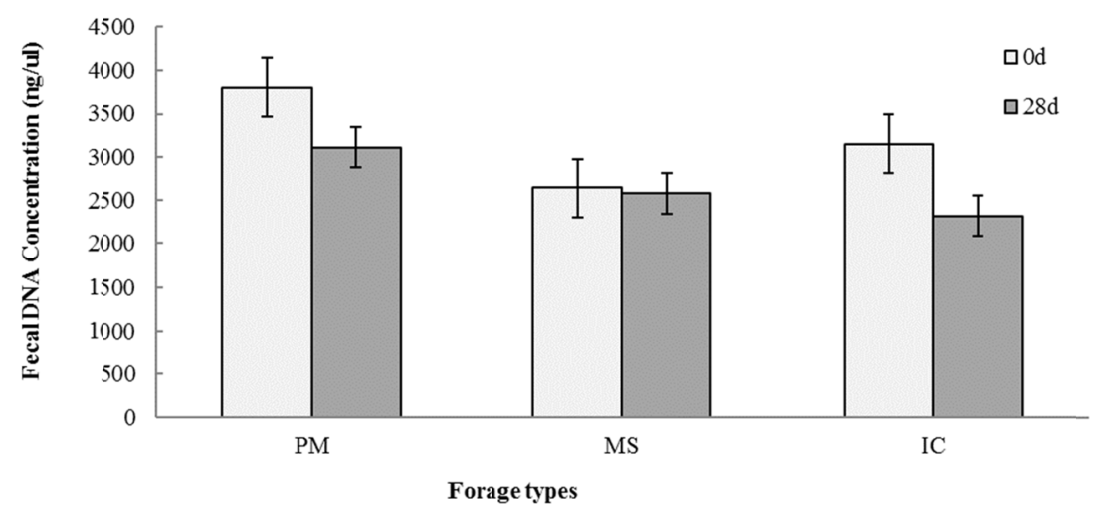

Figure 3. Fecal microbial DNA concentration in goats fed pearl millet (PM), Mississippi silver (MS), and Iron and Clay (IC) cowpea

\subsection{Serum Total Protein Concentration}

The average initial (day 0) serum protein concentration in goats was $908.52 \mathrm{mg} / \mathrm{ml}$. Serum protein concentration was not affected by forage type grazed by the goats $(P=0.1921)$ as shown in Figure 4 .

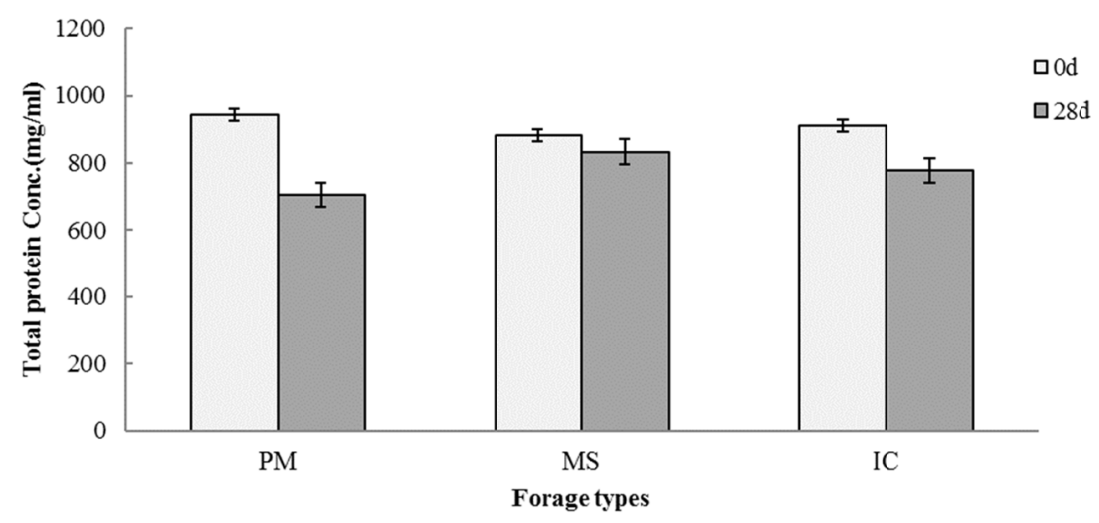

Figure 4. Total protein concentration in serum from goats fed Pearl Millet (PM), Mississippi silver (MS), and Iron and Clay (IC) cowpea

\subsection{PGE2}

Feed type treatment had no effect on PGE2 secreted levels, however, a significant time effect $(P<0.05)$ was observed. Overall the PGE2 concentration decreased from $585.43 \pm 69.65 \mathrm{ng} / \mathrm{ml}(0 \mathrm{~d})$ to $2.03 \pm 0.66 \mathrm{ng} / \mathrm{ml}(28 \mathrm{~d})$ in the cowpea grazed goats.

\subsection{Effect of Cowpea Pasture on TAC}

The effect of cowpea pasture grazing on total antioxidant capacity in serum is presented in Figure 5. Serum TAC increased in both MS and IC grazed goats at $28 \mathrm{~d}$ compared to PM-grazed animals. 


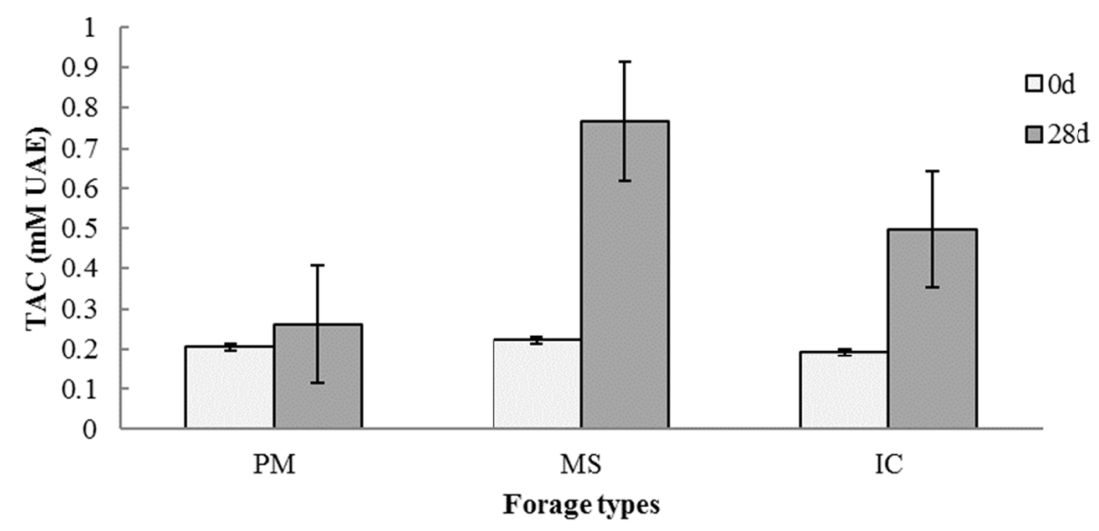

Figure 5. Total antioxidant capacity in serum of goats fed Pearl Millet (PM), Mississippi silver (MS), and Iron and Clay (IC) cowpea. Error bar represent SEM

\subsection{Correlation Results}

Association between phenotypic parameters measured is presented in Table 3. Body weight in goats positively correlated with BCS, TAC, \% neutrophils count, and PGE2, but a weak negative correlation with FAMACHA score, total serum protein concentration, and \% lymphocytes was observed. A strong negative association was observed between $\%$ lymphocytes counts and \% neutrophils count $\left(r=-0.91 ; r^{2}=-0.83\right)$. Total antioxidant capacity (TAC) was positively correlated with total serum protein concentration $(r=0.38), \%$ neutrophils count $(r=0.35)$, and PGE2 $(r=0.53), \%$ lymphocytes count $(r=-0.40)$. However, there were no association between fecal egg count (FEC) and PCV, total protein, \% lymphocytes, and PGE2.

Table 3. Correlation analysis between phenotypic parameters measured in goats

\begin{tabular}{lllllllllll}
\hline & PCV & FAMACHA & TP & LYM & NEU & PGE2 & TAC & FEC & BCS & BW \\
\hline PCV & 1 & & & & & & & & & \\
TP & 0.39 & -0.30 & 1 & & & & & & & \\
LYM & 0.087 & -0.097 & 0.25 & 1 & & & & & & \\
NEU & 0.064 & 0.041 & -0.13 & -0.91 & 1 & & & & & \\
PGE2 & 0.091 & -0.23 & 0.17 & -0.29 & 0.29 & 1 & & & & \\
TAC & 0.32 & -0.27 & 0.38 & -0.40 & 0.35 & 0.53 & 1 & & & \\
FEC & 0.049 & 0.29 & 0.045 & 0.057 & -0.15 & 0.0030 & 0.17 & 1 & & \\
BCS & -0.13 & -0.24 & 0.038 & 0.0086 & -0.19 & 0.27 & 0.25 & -0.24 & 1 & \\
BW & 0.13 & -0.16 & -0.10 & -0.26 & 0.15 & 0.34 & 0.17 & 0.053 & 0.30 & 1 \\
\hline
\end{tabular}

Note. PCV: Packed cell volume; TP: Total protein concentration; LYM: Lymphocyte; NEU: Neutrophil; PGE2: Prostaglandin E 2; TAC: Total antioxidant capacity; FEC: Fecal egg count; BCS: Body condition score; BW: Body weight.

\section{Discussion}

In this study, the effect of freshly grazed cowpea forage on health and production parameters were evaluated in goats. Cowpea forage especially MS variety had an impact on growth and the health of the goats used in the study. Cowpea forage is nutritious (Sreerama et al., 2012), and therefore is comparable to other notable forage legumes such as alfalfa, soybean. Results from this study indicated high crude protein content in cowpea forage and this corroborates results from previous reports (Ishiaku, 2016; Katsande et al., 2016). In ruminant diet, protein is one of the major limiting nutrient (Gusha et al., 2014; Mapiye et al., 2014). Feed supplements that are able to correct this deficiency are necessary. Cowpea, as a feed resource is high in protein and phosphorus (Baloyi et al., 2008), and has been suggested as a suitable protein supplement to small ruminants on poor roughage diets (Etana et al., 2013). Also, leguminous forages including cowpea, compared to grasses and crop residues have high potential degradation and digestibility because it has low cell-wall content; and a high proportion of thin-wall non-lignified mesophyll tissues (Baloyi et al., 2008). Furthermore, theinclusion of 
legume forages increases feed intake and especially cowpea forage has demonstrated a positive nitrogen balance in goats (Asaolu et al., 2011). Katsande et al. (2016) also observed a high nitrogen and microbial protein syntheses, which helps supply about two-thirds of the amino acid absorbed by ruminants (Pathak, 2008). Our study findings showed that goats grazed on cowpea forage had high growth performance than those on pearl millet , this was consistent with previous findings (Adeloye et al., 1995).

The experimental goats were healthy and no incidence of disease or infection were observed during the study period. Health parameters including PCV, FAMACHA, and WBC measured in the current study indicated no adverse effect of cowpea forage on goats. In addition to the nutritional constituents, cowpea forage contains phenolic compounds including flavonoid and tannins (Cai et al., 2003) that are beneficial for health. Cowpea forages analyzed in this study contained phenolic compound including tannins, and this result was similar to observations of previous studies (Adjei-Fremah et al., 2015; Ojwang et al., 2015). Katsande et al. (2016) reported about $1.2 \mathrm{~g} / \mathrm{kg} \mathrm{DM}$ tannin content in cowpea forage. Results from the current study showed that cowpea forage may have anthelmintic effect in goats as shown by reduction of FEC and fecal microbial DNA concentration. Previous studies have demonstrated the anthelmintic potentials of polyphenol-rich forages sulla (Hedysarum coronarium; Niezen et al., 1995), sericea lespedeza (Lespedeza cuneata; Min et al., 2004), sainfoin (Onobrychus viciifolia; Heckendorn et al., 2006), birdsfoot trefoil (L. corniculatus; Heckendorn et al., 2007). Sericea lespedeza, rich in condensed tannins reduced FEC (Min et al., 2004) when grazed as fresh forage (Terrill et al., 2009; Mechineni et al., 2014) and a similar observation was shown in the current study. Also, cowpea may impact gut health in goats as observed in reduction in microbial DNA levels (Qin et al., 2010; Malinen et al., 2005).

Results from the current study demonstrates the effect of cowpea forage grazing on markers of immunity and inflammation. In goats fed cowpea forage a lower PGE2 level in serum was observed. The production of proinflammatory cytokines is an essential component of the innate immune response, and they have the ability to activate neutrophils (Karcher et al., 2014; Koh et al., 2007). Prostaglandin E2, an eicosanoid is a mediator of inflammation. Reduction of serum PGE2 levels may suggest a possible anti-inflammatory action of cowpea feed in goats. The anti-inflammatory potential of cowpea seeds have been tested (Ojwang et al., 2015), and the anti-inflammatory effect of cowpea polyphenols in bovine blood have also been reported (Adjei-Fremah et al., 2017). Cowpea forage may, therefore, possess anti-inflammatory effects in goats due to the presence of polyphenols and their antioxidant potential and this requires further studies. Interestingly, the total antioxidant capacity in serum increased in cowpea grazed goats. Previous in vitro studies have shown the antioxidant capacity of cowpea polyphenol extract in the bovine blood (Adjei-Fremah et al., 2015), and cowpea's possible impact in combating oxidative stress in livestock. Worku et al. (2016), showed that diet may impact innate immune response biomarkers and gene expression in goats. Overall, the results from the present study suggest that cowpea forages have beneficial health effect in goats.

\section{Conclusion}

In conclusion, this study showed the production and health benefits of fresh cowpea forage grazing to goats. The MS cowpea forage especially increased body weight, decreased gastrointestinal parasite counts (FEC and fecal microbial DNA concentration), and modulated the concentration of biomarkers of immunity/inflammation including PGE2, and total antioxidant capacity in serum. Cowpea is a widely adapted and economical forage and results from this study suggest favorable benefits of integration of cowpea as a fresh forage into small ruminant feeding system. Further study is needed to understand the molecular impact, mechanism, and regulation of cowpea forage on immunity and inflammation in goats.

\section{Acknowledgements}

The authors are grateful for the assistance of Agnes Everett, Roberto Franco, Keesla Moultone, Emmanuel Asiamah, Kingsley Ekwemalor, and Hamid Ismail.

\section{References}

Adeloye, A. A. (1995). The value of cowpea husk to the goat. Bioresource Technology, 52(3), 281-282. https://doi.org/10.1016/0960-8524(94)00145-Q

Adjei-Fremah, S. (2017). Molecular Effects of Cowpea Polyphenols on Mammalian Transcriptome, Proteome, and Microbiome (Doctoral dissertation, North Carolina Agricultural and Technical State University). Retrieved from https://search.proquest.com/docview/1916583456?pq-origsite=gscholar 
Adjei-Fremah, S., Asiamah, E. K., Ekwemalor, K., Jackai, L., Schimmel, K., \&Worku, M. (2016a). Modulation of bovine Wnt signaling pathway genes by cowpea phenolic extract. Journal of Agricultural Science, 8(3), 21-35. https://doi.org/10.5539/jas.v8n3p21

Adjei-Fremah, S., Asiamah, E., Ekwemalor, K., Osei, B., Ismail, H., Jackai, L. E., \& Worku, M. (2017). 055 The anti-inflammatory effect of cowpea polyphenol in bovine blood. Journal of Animal Science, 95(Suppl. 4), 27-27. https://doi.org/10.2527/asasann.2017.055

Adjei-Fremah, S., Everett, A., Franco, R., Moultone, K., Asiamah, E., Ekwemalor, K., ... Worku, M. (2016). 0166 Health and production benefits of feeding cowpeas to goats. Journal of Animal Science, 94(Suppl. 5), 80-81. https://doi.org/10.2527/jam2016-0166

Adjei-Fremah, S., Jackai, L. E., \& Worku, M. (2015). Analysis of phenolic content and antioxidant properties of selected cowpea varieties tested in bovine peripheral blood. American Journal of Animal and Veterinary Sciences, 10(4), 235-245. https://doi.org/10.3844/ajavsp.2015.235.245

Adjei-Fremah, S., Jackai, L. E., Schimmel, K., \&Worku, M. (2016). 0179 Immunomodulatory activities of polyphenol extract from cowpea (Vigna unguiculata) on bovine polymorphonuclear neutrophils. Journal of Animal Science, 94(Suppl. 5), 86-87. https://doi.org/10.2527/jam2016-0179

Adjei-Fremah, S., Jackai, L. E., Schimmel, K., \&Worku, M. (2016b). Microarray analysis of the effect of cowpea (Vigna unguiculata) phenolic extract in bovine peripheral blood. Journal of Applied Animal Research, 46(1), 100-106. https://doi.org/10.1080/09712119.2016.1264305

Asaolu, V. O., Binuomote, R. T., Akinlade, J. A., Oyelami, O. S., \& Kolapo, K. O. (2011). Utilization of Moringa oleifera fodder combinations with Leucaena leucocephala and Gliricidia sepium fodders by West African Dwarf Goats. International Journal of Agricultural Research, 6(8), 607-619. https://doi.org/ 10.3923/ijar.2011.607.619

Asiamah, E. K., Adjei-Fremah, S., Osei, B., Ekwemalor, K., \& Worku, M. (2016). An extract of Sericea Lespedeza modulates production of inflammatory markers in pathogen associated molecular pattern (PAMP) activated ruminant blood. Journal of Agricultural Science, 8(9), 1-9. https://doi.org/10.5539/jas.v8n9p1

Association of Official Analytical Chemists. (2000). Official Methods of Analysis (17th ed.). AOAC, Arlington, VA.

Baloyi, J. J., Ngongoni, N. T., \& Hamudikuwanda, H. (2008). The effect feeding forage legumes as nitrogen supplement on growth performance of sheep. Tropical Animal Health and Production, 40(6), 457-462. https://doi.org/10.1007/s11250-007-9120-3

Cai, R., Hettiarachchy, N. S., \&Jalaluddin, M. (2003). High-performance liquid chromatography determination of phenolic constituents in 17 varieties of cowpeas. Journal of Agricultural and Food Chemistry, 51(6), 1623-1627. https://doi.org/10.1021/jf020867b

Ekwemalor, K., Asiamah, E. K., Adjei-Fremah, S., \& Worku, M. (2016). Effect of a Mushroom (Coriolus versicolor) Based Probiotic on Goat Health. American Journal of Animal and Veterinary Sciences, 11(3), 108-118. https://doi.org/10.3844/ajavsp.2016.108.118

Etana, A., Tadesse, E., Mengistu, A., \& Hassen, A. (2013). Advanced evaluation of cowpea (Vigna unguiculata) accessions for fodder production in the central rift valley of Ethiopia. Journal of Agricultural Extension and Rural Development, 5(3), 55-61. https://doi.org/10.5897/JAERD12.128

Foster, J. L., Adesogan, A. T., Carter, J. N., Blount, A. R., Myer, R. O., \& Phatak, S. C. (2009). Intake, digestibility, and nitrogen retention by sheep supplemented with warm-season legume hays or soybean meal. Journal of Animal Science, 87(9), 2891-2898. https://doi.org/10.2527/jas.2008-1637

Gusha, J., Halimani, T. E., Katsande, S., \& Zvinorova, P. I. (2014). Performance of goats fed on low quality veld hay supplemented with fresh spiny cactus (Opuntia megacantha) mixed with browse legumes hay in Zimbabwe. Tropical Animal Health and Production, 46(7), 1257-1263. https://doi.org/10.1007/s11250014-0636-Z

Hamilton, A. M., Worku, M., Thompson, H. L., \& Adjei-Fremah, S. (2017). 066 Goat parasite incidence and host resilience in North Carolina during the fall season. Journal of Animal Science, 95(Suppl. 4), 33-33. https://doi.org/10.2527/asasann.2017.066 
Heckendorn, F., Häring, D. A., Maurer, V., Senn, M., \& Hertzberg, H. (2007). Individual administration of three tanniferous forage plants to lambs artificially infected with Haemonchus contortus and Cooperia curticei. Veterinary Parasitology, 146(1), 123-134. https://doi.org/10.1016/j.vetpar.2007.01.009

Heckendorn, F., Häring, D. A., Maurer, V., Zinsstag, J., Langhans, W., \& Hertzberg, H. (2006). Effect of sainfoin (Onobrychis viciifolia) silage and hay on established populations of Haemonchus contortus and Cooperiacurticei in lambs. Veterinary Parasitology, 142(3), 293-300. https://doi.org/10.1016/j.vetpar. 2006.07.014

Ishiaku, Y. M. (2016). Effect of plant spacings on yield and quality of Columbus grass (Sorghum almum) under rainfed condition in Shika, Nigeria. Journal of Animal Production Research, 28(1), 318-328.

Kaplan, R. M., Burke, J. M., Terrill, T. H., Miller, J. E., Getz, W. R., Mobini, S., ... Vatta, A. F. (2004). Validation of the FAMACHAC eye color chart for detecting clinical anemia in sheep and goats on farms in the southern United States. Veterinary Parasitology, 123(1), 105-120. https://doi.org/10.1016/j.vetpar. 2004.06.005

Kaplan, R. M., Klei, T. R., Lyons, E. T., Lester, G., Courtney, C. H., French, D. D., ... Zhao, Y. (2004). Prevalence of anthelmintic resistant cyathostomes on horse farms. Journal of the American Veterinary Medical Association, 225(6), 903-910. https://doi.org/10.2460/javma.2004.225.903

Karcher, E. L., Hill, T. M., Bateman, H. G., Schlotterbeck, R. L., Vito, N., Sordillo, L. M., \& Vande Haar, M. J. (2014). Comparison of supplementation of n-3 fatty acids from fish and flax oil on cytokine gene expression and growth of milk-fed Holstein calves. Journal of Dairy Science, 97(4), 2329-2337. https://doi.org/10.3168/jds.2013-7160

Katsande, S., Baloyi, J. J., Nherera-Chokuda, F. V., Ngongoni, N. T., Matope, G., Zvinorova, P. I., \& Gusha, J. (2016). Apparent digestibility and microbial protein yield of Desmodium uncinatum, Mucuna pruriens and Vigna unguiculata forage legumes in goats. African Journal of Range \& Forage Science, 33(1), 53-58. https://doi.org/10.2989/10220119.2015.1043646

Koh, A., Da Silva, A. P. B., Bansal, A. K., Bansal, M., Sun, C., Lee, H., ... Zohar, R. (2007). Role of osteopontin in neutrophil function. Immunology, 122(4), 466-475. https://doi.org/10.1111/j.1365-2567.2007. 02682.x

Malinen, E., Rinttilä, T., Kajander, K., Mättö, J., Kassinen, A., Krogius, L., ... Palva, A. (2005). Analysis of the fecal microbiota of irritable bowel syndrome patients and healthy controls with real-time PCR. The American Journal of Gastroenterology, 100(2), 373. https://doi.org/10.1111/j.1572-0241.2005.40312.x

Mapiye, C., Chimonyo, M., Marufu, M. C., \& Dzama, K. (2011). Utility of Acacia karroo for beef production in Southern African smallholder farming systems: A review. Animal Feed Science and Technology, 164(3), 135-146. https://doi.org/10.1016/j.anifeedsci.2011.01.006

Mechineni, A., Kommuru, D. S., Gujja, S., Mosjidis, J. A., Miller, J. E., Burke, J. M., ... Kouakou, B. (2014). Effect of fall-grazed sericea lespedeza (Lespedeza cuneata) on gastrointestinal nematode infections of growing goats. Veterinary Parasitology, 204(3), 221-228. https://doi.org/10.1016/j.vetpar.2014.06.002

Min, B. R., Pomroy, W. E., Hart, S. P., \& Sahlu, T. (2004). The effect of short-term consumption of a forage containing condensed tannins on gastro-intestinal nematode parasite infections in grazing wether goats. Small Ruminant Research, 51(3), 279-283. https://doi.org/10.1016/S0921-4488(03)00204-9

Molento, M. B. (2009). Parasite control in the age of drug resistance and changing agricultural practices. Veterinary Parasitology, 163(3), 229-234. https://doi.org/10.1016/j.vetpar.2009.06.007

Mubi, A. A., Midau, A., \& Hamdalla, S. J. (2015). Performance of Red Sokoto Goats Fed Maize Offal and Cowpea Husk at Graded Levels as Supplement before Grazing. J. Anim Sci. Adv., 5(1), 1157-11161. https://doi.org/10.5455/jasa.20141230103545

Niezen, J. H., Waghorn, T. S., Charleston, W. A. G., \& Waghorn, G. C. (1995). Growth and gastrointestinal nematode parasitism in lambs grazing either lucerne (Medicago sativa) or sulla (Hedysarum coronarium) which contains condensed tannins. The Journal of Agricultural Science, 125(02), 281-289. https://doi.org/10.1017/S0021859600084422

Obanla, T., Adjei-Fremah, S., Gyawali, R., Zimmerman, T., Worku, M., \& Ibrahim, S. A. (2016). Effects of Long Term Exposure to Aspirin on Growth, Functionality and Protein Profile of Lactobacillus rhamnosus (LGG) (ATCC 53103). Journal of Food Research, 5(4), 46. http://dx.doi.org/10.5539/jfr.v5n4p46 
Ojwang, L. O., Banerjee, N., Noratto, G. D., Angel-Morales, G., Hachibamba, T., Awika, J. M., \& Mertens-Talcott, S. U. (2015). Polyphenolic extracts from cowpea (Vigna unguiculata) protect colonic myofibroblasts (CCD18Co cells) from lipopolysaccharide (LPS)-induced inflammation-modulation of microRNA 126. Food \& Function, 6(1), 145-153. https://doi.org/10.1039/C4FO00459K

Pathak, A. K. (2008). Various factors affecting microbial protein synthesis in the rumen. Veterinary World, 1(6), 186-189.

Pitman, W. D., Walker, R. S., Scaglia, G., Buckley, B., Alison, M. W., Han, K. J., ... Gentry, G. (2015). Summer legumes for creep grazing in cow-calf production on bermudagrass pasture. Journal of Agricultural Science, 7(8), 8-17. https://doi.org/10.5539/jas.v7n8p8

Price, M. L., Van Scoyoc, S., \& Butler, L. G. (1978). A critical evaluation of the vanillin reaction as an assay for tannin in sorghum grain. Journal of Agricultural and Food Chemistry, 26(5), 1214-1218. doi/pdf/10.1021/jf60219a031

Qin, J., Li, R., Raes, J., Arumugam, M., Burgdorf, K. S., Manichanh, C., ... Mende, D. R. (2010). A human gut microbial gene catalog established by metagenomic sequencing. Nature, 464(7285), 59. https://doi.org/ 10.1038/nature08821

Roeber, F., Jex, A. R., \& Gasser, R. B. (2013). Impact of gastrointestinal parasitic nematodes of sheep, and the role of advanced molecular tools for exploring epidemiology and drug resistance-An Australian perspective. Parasites \& Vectors, 6(1), 153-166. https://doi.org/10.1186/1756-3305-6-153

Schmidt, J. R., Miller, M. C., Andrae, J. G., Ellis, S. E., \&Duckett, S. K. (2013). Effect of summer forage species grazed during finishing on animal performance, carcass quality, and meat quality. Journal of Animal Science, 91(9), 4451-4461. https://doi.org/10.2527/jas.2012-5405

Singh, B. B., Ajeigbe, H. A., Tarawali, S. A., Fernandez-Rivera, S., \& Abubakar, M. (2003). Improving the production and utilization of cowpea as food and fodder. Field Crops Research, 84(1), 169-177. https://doi.org/10.1016/S0378-4290(03)00148-5

Singh, S. K., Kakani, V. G., Surabhi, G. K., \& Reddy, K. R. (2010). Cowpea (Vigna unguiculata [L.] Walp.) genotypes response to multiple abiotic stresses. Journal of Photochemistry and Photobiology B: Biology, 100(3), 135-146. https://doi.org/10.1016/j.jphotobiol.2010.05.013

Singleton, V. L., Orthofer, R., \& Lamuela-Raventós, R. M. (1999). Analysis of total phenols and other oxidation substrates and antioxidants by means of Folin-ciocalteureagent. Methods in Enzymology, 299C, 152-178. https://doi.org/10.1016/S0076-6879(99)99017-1

Sreerama, Y. N., Sashikala, V. B., Pratape, V. M., \& Singh, V. (2012). Nutrients and antinutrients in cowpea and horse gram flours in comparison to chickpea flour: Evaluation of their flour functionality. Food Chemistry, 131(2), 462-468. https://doi.org/10.1016/j.foodchem.2011.09.008

Terrill, T. H., Dykes, G. S., Shaik, S. A., Miller, J. E., Kouakou, B., Kannan, G., ... Mosjidis, J. A. (2009). Efficacy of sericea lespedeza hay as a natural dewormer in goats: Dose titration study. Veterinary Parasitology, 163(1), 52-56. https://doi.org/10.1016/j.vetpar.2009.04.022

Van Wyk, J. A. (2001). Refugia--overlooked as perhaps the most potent factor concerning the development of anthelmintic resistance. The Onderstepoort Journal of Veterinary Research, 68(1), 55.

Worku, M., Abdalla, A., Adjei-Fremah, S., \& Ismail, H. (2016). The impact of diet on expression of genes involved in innate immunity in goat blood. Journal of Agricultural Science, 8(3), 1-9. https://doi.org/ $10.5539 /$ jas.v8n3p1

\section{Copyrights}

Copyright for this article is retained by the author(s), with first publication rights granted to the journal.

This is an open-access article distributed under the terms and conditions of the Creative Commons Attribution license (http://creativecommons.org/licenses/by/4.0/). 